\title{
Educational Gender Gap, Economic Growth and Income Distribution: An Empirical Study of the Interrelationship in Cameroon
}

\author{
Dobdinga C. Fonchamnyo ${ }^{1} \&$ Nubonyin Hilda Fokong ${ }^{1}$ \\ ${ }^{1}$ Department of Economics, Faculty of Economics and Management Sciences, The University of Bamenda, \\ Cameroon \\ Correspondence: Dobdinga C. Fonchamnyo, Department of Economics, Faculty of Economics and Management \\ Sciences, The University of Bamenda, P. O. Box 39, Cameroon. Tel: 237-677-381-419/237-694-909-800. E-mail: \\ dfonchamnyo@gmail.com
}

Received: December 28, 2016

Accepted: February 9, $2017 \quad$ Online Published: February 20, 2017

doi:10.5539/ijef.v9n3p168

URL: https://doi.org/10.5539/ijef.v9n3p168

\begin{abstract}
This study aimed at investigating the interrelationship existing between educational gender gap, economic growth and income distribution in Cameroon using time series data from 1970 to 2014 obtained from the World Bank Development indicators and University of Texas inequality project. For estimation, the three stage least square regression technique was employed to estimate the parameters of the system of equations. The econometrics results showed that, educational gender gap had a positive and significant effect on economic growth, while increase in income inequality deters growth in Cameroon. The results also revealed that the theil index of income inequality negatively and significantly affect the educational gender gap, while the proportion of female teachers in the labour force and trade openness had a positive influence on the educational gender gap. Based on the findings, it is recommended that policymakers should focus on socio-economic policies apt to reduce educational gender gap and income inequality and at promoting economic growth.
\end{abstract}

Keywords: educational gender gap, income distribution, growth, Cameroon

\section{Introduction}

The elimination of gender gap from the societies has remained a sad reality, despite the greater international awareness about gender issues (Augusto \& Saadia, 2005). This argument is not quite different from Cameroon. One has to concede therefore that achieving gender equality in Cameroon is not an easy issue. Specifically, from 1993 onwards reports by the UNDP (1995), World Bank (1994) and the Cameroon's Ministry of Planning and Regional Development all showed that the education status of girls and women is generally unsatisfactory compared to that of boys and men. Similarly, statistics presented by Njeuma (1998) revealed that, the incidence of illiteracy is still high among adult women (about 70\%) compared to adult men (about 45\%). Thus, Njeuma concludes that, an unequal importance is given to the education of a girl compared to the boy child.

Other statistics from studies carried out by international organizations tell a similar story. UNICEF (2009) showed that the ratio of girls to boys in primary education has increased marginally from $84.1 \%$ in 2006 to $85.1 \%$ in 2009. Precisely, primary school enrolment rates in Cameroon have increased from $69.5 \%$ in 1991 to $88.3 \%$ in 2008 with primary school completion rates increasing from $53.1 \%$ to $72.7 \%$ over the same period. However, according to UNICEF (2009), the girl's national dropout rates are high to the extent that the net enrolment figure for secondary education has dropped to $20 \%$. Given that females' educational opportunities remain significantly lower than that of males the government has to concede, however, that achieving gender equality in Cameroon is a problem. For this reason, the National Policy for Education in Cameroon Section 4 of Law No. 98/004 of $14^{\text {th }}$ April 1998 states that, "Education shall be top priority". Yet, Global Gender Gap Report of Hausmann et al. (2012) avers that, literacy rate has remained 63 for female as against 79 for male in 2012 representing a value of 0.80 . This value implies educational gender inequality.

Also, in 1999, in order to increase school enrolments the government declared that public school fees in primary schools should be eliminated (Kattan, 2006). Although this policy has been implemented by the state, educational gender gap still exists. Specifically, the ratio of females' to males' primary enrolment in education is $86: 99$ or $86 \%$ females to $99 \%$ males. This indicates a value of 0.87 . The ratio of females' to males' secondary enrolment in education is 10:18. This depicts a value of 0.56 . The ratio of females' to males' tertiary enrolment 
in education is 10:13, thus a variable of 0.78 (Hausmann et al., 2012). The above ratios reflect the presence of educational gender inequality in the society as a whole.

Furthermore, in an attempt to improve on the educational gender gap and increase economic growth, the government of Cameroon adopted the Plato's argument which implies that, a considerable part of the community's wealth must be invested in education (Tilak, 1989). Thus, in Cameroon, education has continued to take the largest share of the government's budget. For instance, the Finance Bill for the year 2011 states that in 2010 , the resources allocated to this sector represented $14.9 \%$ of the state budget. That is, an appropriation of 375.3 billion.

Notwithstanding the huge budget oriented to the supply side, Hausmann et al. (2012) report on gender inequality showed that, Cameroon in 2012 ranked 112 of 135 countries in the Gender Gap Index. Also she ranked 126 of 135 countries in global gender educational attainment which denotes inequality since she scored 0.629 . In terms of economic growth, the gross domestic production in purchasing power parity (PPP, US\$, in billions of US dollars) per capita for Cameroon in 2012 was 2.058 (Hausmann et al., 2012). Precisely, Cameroon's growth rate of Gross Domestic Product (GDP) stood at an average of 5.7\% between 1960 to1970. Between 1980 and 1992 GDP declined from a negative 4.02\% in 1987 to negative 4.34\% in 1992 (Njimanted, 2010). From 2000 onwards the annual growth rate was on a downward trajectory with only $2.9 \%$ in 2008 and $1.9 \%$ growth in 2009 (Finance Bill, 2011). Therefore, over the period of 39 years (1970 to 2009) real GDP and real per capita income of Cameroon have fallen by $40 \%$ and $74 \%$ respectively (Njimanted, 2010). This means she has not attained the 5.5\% as projected in the GESP (2009) which was focused on accelerating growth amongst other goals.

Using financing from the Heavily Indebted Poor Countries (HIPC) initiative, Cameroon has directed poverty reduction resources largely to the education and health sectors (Kattan, 2006). Thus, it is necessary to have a closer look at the indicators of human capital in order to evaluate the magnitude of educational - gender gap. A comparative analysis of global gender gap in educational attainment vis-à-vis health and survival depicts that; whereas, Cameroon in educational attainment scored 0.860 in 2011 and 0.782 in 2012; in health and survival Cameroon scored 0.961 in 2011 and 2012 respectively (Hausmann et al., 2012). The above results indicate that the performance in education is worse than that of health and survival.

Moreover, in October 2000 the government adopted a policy to eliminate disparities between boys and girls and develop vocational educational and professional training (IMF, 2003). It is apparent that since the government adopted the above policy, the scenario in the labour market has not reflected any improvement in the educational gender gap. This can be better buttressed by the fact that in 2012, 54 female Cameroonians participated in the labour force as opposed to 82 male Cameroonians representing a value of 0.66 (Hausmann et al., 2012). In terms of estimated earned income, female Cameroonians earned 1.843 (PPP US\$) as against 2.925 (PPP US\$) for their male counterparts daily. This gives a value of 0.63 (Hausmann et al., 2012). The above ratios of labour force participation and estimated income earned indicate inequality. Consequently, educational gender gap in relation to labour force participation and income leave much to be desired.

It is against this backdrop that the objective of this study is to examine the linkage existing between educational gender gap, economic growth and income distribution in Cameroon using a three stage least squares estimation technique. The rest of the paper is organized as follows; the section on literature review makes an overview of the existing empirical literature on the relationship between gender educational gap, economic growth and income inequality, while the section on estimation framework and data description presents the estimation methodology and describes the data used in the analyses. The empirical results obtained through the three stage least squares are presented and discussed in section four, while the last section presents the conclusion and policy implications of the study.

\section{Literature Review}

Theories that provide some insights in the understanding of the transmission process between educational gender gap, economic growth and income distribution include; the theory of human capital, endogenous growth theories and personal income distribution theory. Becker (1993) asserts that, the core of the human capital theory lies in the thesis that, education increases productivity of the labour force leading to increase in economic growth. Based upon the works of Psacharopoulos and Woodhall (1997) and Olaniyan and Okemakinde (2008), the human capital theorists assume that an educated population is a productive population.

Similarly, the theories developed by Lucas (1988) and Romer (1990) state that knowledge and ideas are essential for an economy to grow. They assumed that economic growth comes from technological change which is considered endogenous in the model. This implies that output growth can be enhanced by promoting both physical and human capital. Accordingly, Henderson and Poole (1991) using the theory of personal income 
distribution also called the marginal productivity theory assumed that each factor is paid a price according to the value of its marginal product. The value of marginal product is a factor that depends on the educational level (credentials or skills or aptitude), motivation, regional location, age, rate of population growth, standard of civilization reached and profession.

On the empirical fronts many researchers (Hill \& King, 1993 and 1995) who studied the effect of female education on growth, obtained results suggesting that the level of female education has a statistical significant and positive effect on economic growth (GDP). Their results also showed that large gender gaps in school enrolments had a negative effect on GDP. Also Barro and Lee (2000) using data from 100 countries from 1960 to 1995 revealed that, years of school attainment at the secondary and higher levels for males age 25 and over had a positive and significant effect on the subsequent rate of economic growth as opposed to females. The results suggested that highly educated women were not well utilized in the labor markets of many countries. This was because education of women at the primary level stimulates economic growth indirectly by inducing a lower fertility rate.

Klasen (2002) as well as Klasen and Lamanna (2008) reported that, gender gap in education negatively and significantly reduces the level of GDP per capita. The authors argued gender gap in education reduces economic growth through its effects on investment rates. Chaudhry (2007) found that gender gap in initial education reduces economic growth. The results in this study are consistent with those of Baliamoune-Lutz and McGillivray (2007), who found out that gender gaps in literacy have a negative effect on growth.

In similar studies, Tinbergen (1972), Checchi (2001) and Digdowiseiso (2009) found that, higher human capital inequality leads to higher income inequality. Mahmood et al. (2012) in their study obtained results suggesting that educational gap was statistically significant in affecting income inequality. Pose and Tselios (2009) result showed that high levels of inequality in educational attainment are associated with higher income inequality. Their results also showed that ageing population, female participation in the labour force, urbanization, agriculture and industry have a negative effect on inequality, while unemployment and the presence of a strong financial sector positively affect inequality.

In Cameroon, Baye and Epo (2009) inter-temporal decompositions highlighted that education more than overwhelmingly explained the income gap disparity between 1996 and 2001. Similarly, Baye and Epo (2011) reported that, the joint contribution of education and health in accounting for total inequality was 33\%, indicating the key role human capital characteristics play in explaining observed inequality in the redistribution of household income. However, in the current study the interlinkage between education gender gap, income inequality and economic growth is examined.

\section{Estimation Framework and Data Description}

In order to examine the linkage between income inequality, economic growth and educational gender gap, three equations were estimated - the economic growth equation, income equality equation and educational gender gap equation. These equations are stated as follows;

$$
\begin{gathered}
\text { LGDPP }_{t}=\alpha_{0}+\alpha_{1} L I N_{t}+\alpha_{2} \text { LOPEN }_{t}+\alpha_{3} \text { LTHEIL }_{t}+\alpha_{4} L E G_{t}+\mu_{t} \\
\alpha_{0}>0, \alpha_{1}>0, \alpha_{2}>0, \alpha_{3}<0, \alpha_{4}>0 \\
\text { LTHEIL }_{t}=\beta_{0}+\beta_{1} L G D P P_{t}+\beta_{2} L A D_{t}+\beta_{3} L E G_{t}+\beta_{4} L F P R_{t}+v_{t} \\
\beta_{0}>0, \beta_{1}>0, \beta_{2}<0, \beta_{3}<0, \beta_{4}<0 \\
L E G_{t}=\delta_{0}+\delta_{1} L G D P P_{t}+\delta_{2} L_{T H E I L_{t}}+\delta_{3} L F T_{t}+\delta_{4} L O P E N_{t}+v_{t} \\
\delta_{0}>0, \delta_{1}>0, \delta_{2}<0, \delta_{3}>0, \delta_{4}>0
\end{gathered}
$$

Where LGDPP is the natural logarithm of real GDP per capita; LIN is the natural logarithm of capital investment; LTHEIL is the natural logarithm of income distribution or income inequality; LEG is the natural logarithm of educational gender gap; LOPEN is the natural logarithm of trade openness; LAD is the natural logarithm of age dependency; LFPR is the natural logarithm of the labour force participation rate and LFT is the female teachers in the labour force.

The equations above are the estimated systems or simultaneous equations of the study. The econometric technique used for the study will be evaluated using the identification procedure. The condition for identification requires that $K-M>G-1$; Where: $\mathrm{K}=$ Total number of variables in the system which is eight (8); $\mathrm{M}=$ Number of variables in a particular equation or structural equation (five variables each of the equations); $G=$ Number of structural equations. Given that, the order condition (necessary condition) to test for identification is insufficient, the rank or sufficient condition for identification is satisfied, the sufficient condition requires that an equation is 
identified if it is possible to construct at least one nonzero determinant of order $G-1$ from the coefficient of the variable excluded from a particular equation but contain in another equation of the system. All the equations satisfy this condition for identification. Thus the econometric technique used for estimation of the systems of equation above is the Three Stage Least Square (3SLS). The 3SLS is suitable for the analyses because it is a system method which is applied to all the equations in the model at the same time, thus gives the estimates of all the parameters simultaneously. We have equally chosen the 3SLS to estimate our parameters because the equations give more than enough information to obtain meaningful results.

In order to estimate the equations above, this study made use of secondary data collected from various sources as outline in Table A1 in the Appendix describing the various sources of the data. The data is time series covering the period 1970 to 2014. A detailed definition of the variables used in the study has been presented in Table A1 while the summary statistics is presented in Table 1 .

Table 1. Descriptive statistics of variables used in the estimation

\begin{tabular}{lcccccccc}
\hline Variable & LGDPP & LIN & OPEN & LTHEIL & LAD & LEG & LFPR & LFT \\
\hline Mean & 6.432 & 21.227 & 21.892 & 0.246 & 4.488 & 4.387 & 69.151 & 22.980 \\
Standard deviation & 0.175 & 0.476 & 0.583 & 0.183 & 0.063 & 0.054 & 1.296 & 2.989 \\
Minimum & 6.119 & 20.193 & 20.806 & 0.338 & 4.362 & 4.226 & 67.662 & 18.975 \\
Maximum & 6.802 & 22.106 & 22.769 & 0.665 & 4.561 & 4.467 & 71.928 & 29.664 \\
Variance & 0.306 & 0.226 & 0.340 & 0.033 & 0.004 & 0.003 & 1.679 & 8.933 \\
Skewness & 0.180 & -0.301 & -0.537 & 0.676 & -0.551 & -0.493 & 0.314 & 0.524 \\
Kutosis & 2.571 & 2.311 & 2.12 & 2.503 & 2.055 & 2.505 & 1.811 & 2.026 \\
Jacque Bera & 2.495 & 1.461 & 3.36 & 1.525 & 3.686 & 2.210 & 3.162 & 3.585 \\
\hline
\end{tabular}

Source: Computed by Authors.

From the statistical analysis in Table 1, labour force participation has the highest mean value whereas; income inequality has the lowest mean value. The standard deviation and variance values of all the variables are less than their mean values. This implies that, all the variables have a good performance. Looking at the skewness, we observe that some of the variables are negative while others positive. The kurtosis values of all our estimated parameters are positive and less than three. Despite the slight skewness in the variables, the Jacque-Bera results indicate that all the variables are normally distributed. Thus, the variables can be used for estimation.

The stationarity test to verify for the presence of unit root is presented in Table 2.

Table 2. Unit root test results

\begin{tabular}{lccccc}
\hline \multicolumn{7}{c}{ Levels } & \multicolumn{3}{c}{ First Difference } & Implied Order & of integration \\
\cline { 1 - 4 } Variable & Test Statistic & P-value & Test Statistic & P-value & \\
\hline LGDPP & -1.718 & 0.4220 & -4.069 & 0.0001 & $\mathrm{I}(1)$ \\
LIN & -1.540 & 0.5136 & -4.857 & 0.0000 & $\mathrm{I}(1)$ \\
LAD & -1.997 & 0.2879 & -3.051 & 0.0304 & $\mathrm{I}(1)$ \\
OPEN & -1.611 & 0.4777 & -5.277 & 0.0000 & $\mathrm{I}(1)$ \\
LEG & -1.575 & 0.4963 & -11.589 & 0.0000 & $\mathrm{I}(1)$ \\
LTHEIL & -0.265 & 0.9303 & -4.560 & 0.0002 & $\mathrm{I}(1)$ \\
LFPR & -0.022 & 0.9604 & -4.042 & 0.0012 & $\mathrm{I}(1)$ \\
LFT & -1.624 & 0.4705 & -3.039 & 0.0314 & $\mathrm{I}(1)$ \\
\hline \multicolumn{7}{c}{ Augmented Dickey Fuller Unit Root Test } & & $\mathrm{I}(1)$ \\
LGDPP & -2.112 & 0.2398 & -4.0977 & 0.0010 & $\mathrm{I}(1)$ \\
LIN & -1.390 & 0.5869 & -4.749 & 0.0001 & $\mathrm{I}(1)$ \\
LAD & -0.7722 & 0.8411 & -3.805 & 0.0029 & $\mathrm{I}(1)$ \\
OPEN & -1.524 & 0.5215 & -8.894 & 0.0000 & $\mathrm{I}(1)$ \\
LEG & -1.430 & 0.5680 & -6.904 & 0.0000 & $\mathrm{I}(1)$ \\
LTHEIL & -0.484 & 0.8952 & -3.849 & 0.0024 & $\mathrm{I}(1)$ \\
LFPR & -1.815 & 0.3732 & -4.086 & 0.0011 & $\mathrm{I}(1)$ \\
LFT & -2.103 & 0.2431 & -2.894 & 0.0461 & \\
\hline
\end{tabular}

Source: Computed by Authors. 
The results showed that the variables are all non-stationary at levels. However, the variables become stationary after the first difference at 5\% level of significance using both the Philips Perron and Augmented Dickey Fuller unit root test. Hence the variables are denoted as I(1), meaning they are stationary after first difference, thus integrated of order one. This implies that in the estimation the first difference of the variables will be used to avoid spurious regression results.

\section{Presentation and Discussion of Results}

As prelude to the estimation and presentation of the regression results, the pairwise correlation results are presented in Table 3. The result from the correlation table shows that there exists a positive relationship between real gross domestic product per capita (LGDPP) and capital investment (LIN), trade openness (LOPEN), educational gender gap (LEG), labour force participation rate (LFPR) and age dependency ratio (LAD).

Table 3. Pairwise correlation results

\begin{tabular}{|c|c|c|c|c|c|c|c|c|}
\hline VAR & LGDPP & LTHEIL & LEG & LIN & LOPEN & LAG & LFPR & LFT \\
\hline LGDPP & 1.000 & & & & & & & \\
\hline LTHEIL & $-0.328 * *$ & 1.000 & & & & & & \\
\hline LEG & $0.418 * * *$ & $-0.578 * * *$ & 1.000 & & & & & \\
\hline LIN & $0.665^{* * *}$ & $0.651 * * *$ & $0.639 * * *$ & 1.000 & & & & \\
\hline LOPEN & $0.508 * * *$ & $0.531 * * *$ & $0.671 * * *$ & $0.575^{* * * *}$ & 1.000 & & & \\
\hline LAD & $0.302 * *$ & $0.564 * * *$ & -0.215 & -0.122 & $-0.393^{*}$ & 1.000 & & \\
\hline LFPR & 0.211 & $0.653 * * *$ & $0.730 * * *$ & $0.580 * * *$ & $0.277 * * *$ & $-0.661 * * *$ & 1.000 & \\
\hline LFT & -0.074 & $0.078 * * *$ & $0.636^{* * * *}$ & 0.237 & $0.582 * * *$ & $-0.614 * * *$ & $0.438 * * *$ & 1.00 \\
\hline
\end{tabular}

Note. $* * *, * *$ and $*$ indicates a $1 \%, 5 \%$ and $10 \%$ level of significance.

Source: Authors' Computation.

This means that, an increase in real gross domestic product per capita is accompanied by an increase in these variables and vice versa. However, income inequality (LTHEIL) and the proportions of female teachers have a negative relationship with real gross domestic product per capita indicating that a decrease in the number of female teachers will result to an increase in real gross domestic product per capita while an increase in the theil index (that is, increase in inequality) will reduce economic growth. The results from the table also showed that there is a positive relationship between educational gender gap, trade openness, capital investment, female labour force participation, real per capita income and number of female teachers. A negative relationship exists between the educational gender gap and income inequality. This implies that a reduction in educational inequality results to a reduction in income inequality.

The empirical results estimated using the 3SLS technique are presented in Table 4. Column one presents the results for the economic growth equation; column two shows the results for the income inequality equation and the last column presents the results for the education gender gap equation.

The quantitative result for the economic growth equation shows that educational gender gap has a positive and statistical significant effect on economic growth. This implies that an increase in the coefficient of the educational gender gap (i.e. a reduction in the inequality in education) results to an increase in economic growth. This finding is compatible with the human capital theory, Meltem (2010) and Morrison et al. (2007) framework for understanding the effects of educational gender equality on poverty reduction, economic growth and income. The effect of inequality on economic growth is negative and statistically significant at the 1 percent level of significance.

Table 4. Empirical results

\begin{tabular}{|c|c|c|c|}
\hline Variables & Economic Growth equation & Income inequality equation & Education gender gap equation \\
\hline & $\begin{array}{c}\text { Coefficient } \\
\text { (Z-Statistics) }\end{array}$ & $\begin{array}{c}\text { Coefficient } \\
\text { (Z-Statistics) }\end{array}$ & $\begin{array}{c}\text { Coefficient } \\
\text { (Z-Statistics) }\end{array}$ \\
\hline LGDPP & - & $\begin{array}{c}-0.5477 \\
(-1.38)\end{array}$ & $\begin{array}{c}0.0636^{* *} \\
(1.87)\end{array}$ \\
\hline LIN & $\begin{array}{c}0.3823 * * * \\
(7.82)\end{array}$ & - & - \\
\hline LOPEN & $\begin{array}{c}0.0475 \\
(0.49)\end{array}$ & - & $\begin{array}{c}0.1314 * * * \\
(4.22)\end{array}$ \\
\hline
\end{tabular}




\begin{tabular}{|c|c|c|c|}
\hline LTHEIL & $\begin{array}{c}-0.2190^{* * * *} \\
(-5.84)\end{array}$ & - & $\begin{array}{c}-0.0306^{* * *} \\
(-4.14)\end{array}$ \\
\hline LEG & $\begin{array}{c}3.6834 * * * \\
(4.52)\end{array}$ & $\begin{array}{c}-0.0099 * * \\
(-2.38)\end{array}$ & - \\
\hline LAD & - & $\begin{array}{c}1.4921^{* * *} * \\
(4.20)\end{array}$ & - \\
\hline LFPR & - & $\begin{array}{c}-0.1657 * * \\
(-2.55)\end{array}$ & - \\
\hline LFT & - & - & $\begin{array}{c}0.0060 * * * \\
(1.87)\end{array}$ \\
\hline Constant & $\begin{array}{c}-19.2535^{* * *} \\
(-6.15)\end{array}$ & $\begin{array}{c}-57.8043 * * * \\
(-6.28)\end{array}$ & $\begin{array}{c}3.9980 * * * \\
(14.64)\end{array}$ \\
\hline Adjusted R-Square & 0.7291 & 0.8925 & 0.8262 \\
\hline $\begin{array}{r}\text { Number } \\
\text { Observations }\end{array}$ & 42 & 42 & 42 \\
\hline Chi 2 & 165.86 & 463.36 & 195.43 \\
\hline $\mathbf{P}$-value & 0.0000 & 0.0000 & 0.0000 \\
\hline
\end{tabular}

Note. $* * *=1 \%, * *=5 \%$ and $* 10 \%$ level of significance.

Endogenous Variables: LGDPP, LTheil, LEG.

Exogenous Variables: LIN, LAG, OPEN, LFPR, LFT.

Source: Authors' computation.

This implies that an increase in income inequality is detrimental to economic growth. Specifically, the results revealed that an increase income inequality by 1 percent will result to a 0.291 percent decrease in economic growth. Other results from the economic growth equation showed that the effect of capital investment and trade openness on economic growth is positive and statistical significant. This result is in line with several authors who have shown that capital investment have a positive impact on growth. For instance, Pervaiz et al. (2011) showed that gross total investment, trade openness and labour force growth positively affect economic growth in Pakistan.

The income inequality results are presented in column two of Table 4. The results showed that real per capita income, educational gender gap and labour force participation rate have a negative effect on income inequality whereas; age dependency ratio has a positive and statistical significant effect on income inequality. This implies that an increase in real per capita income, educational gender gap and labour force participation rate reduces income inequality. Except for real per capita income, all the variables are statistically significant in influencing income inequality. These results are consistent with the findings of Mahmood et al. (2012) who argued that improvement in the educational gender gap is significant in reducing income inequality. The results are also in line with those of De-Gregorio and Lee (2002) research findings that as education expands, returns to education declines and income become more equal.

From the educational gender gap equation, we observe that economic growth has a positive effect on the educational gender gap. The results also showed that the number of female teachers has a positive effect on the educational gender gap. This may simply imply that the presence of female teachers in the teaching core may act as a motivator for girls to continue their education beyond the primary school level. This result is in line with the study of Ahmed and Bakhari (2006). Other results revealed that trade openness has a positive and statistical significant effect on the educational gender gap, while income inequality has a negative and statistical significant effect on education gender gap. This result implies that an increase in the participation of females as teachers reduces the inequality existing in education between males and females, while an increase in inequality increases the educational gender gap between males and females. The findings are consistent with those of Nanfosso and Zamo- Akono (2010).

The results of this study indicate that gender inequality in education will lead to income inequality which is detrimental to growth. The theoretical literature suggests that gender inequality will reduce average human capital, thus harming economic growth. Thus, our results confirm the findings of Digdowiseiso (2009) that, higher human capital inequality leads to higher income inequality. The implication of the aforementioned discussions is that countries with higher levels of female labour force participation rate are more likely to have an improvement in the educational gender gap leading to an improvement in income inequality. Thus, such countries will have a higher level of productivity. 


\section{Conclusion and Policy Recommendations}

This study offered an empirical test of the interrelationship existing between educational gender gap, economic growth and income inequality in Cameroon. To achieve this, secondary data was collected from the World Development Indicators (WDI) while the three stage least square (3SLS) estimation technique was employed to estimate the system of equations developed. The quantitative results showed that educational gender gap has a positive and statistical significant effect on economic growth and income distribution. That is, a reduction in the education gender gap will result to an increase in economic growth and an improvement in the fairness in income distribution. This therefore means that a significant constraint to higher economic growth and income distribution in Cameroon appears to be the substantial gender inequality persisting in education.

The results also showed that economic growth has a positive and statistical significant effect on the educational gender gap, while a negative and statistical insignificant effect exists between economic growth and income inequality. The results further showed that an increase in income inequality affects economic growth and the educational gender gap negatively. Other results from the study showed that trade openness and capital investment play a positive and statistical significant role in influencing economic growth. Trade openness was also found to have a positive and statistical significant effect on the educational gender gap.

The findings from this study indicate salient policy elements that can be implemented to carry the economy ahead. There is need for an improvement in the educational gender gap (that is, increasing equality in gender education) in order to propel economic growth and reduce income inequality. It is also important to foster trade openness as this improves economic growth, and reduces the income inequality and education gender gap. Employment of females, especially female teachers should be encouraged as this plays a key role in promoting female education, and reducing the educational gender gap which has a multiplier effect on both economic growth and income distribution. Policies should also be put in place to improve on capital investment and trade openness, since they are key promoters of economic growth.

\section{References}

Ahmed, N., \& Bukhari, H. K. (2006). Gender Inequality and Trade Liberalisation: A Case Study of Pakistan. MPRA Paper no. 16252

Augusto, L., \& Saadia, Z. (2005). Women's Empowerment: Measuring the Global Gender Gap. World Economic Forum.

Baliamoune-Lutz, M., \& McGillivray, M. (2007). Gender Inequality and Growth: Evidence from Sub-Saharan Africa and Arab Countries. ICER Turin, Italy.

Barro, R. J., \& Lee, J. W. (2000). International data on educational attainment updates and National implications. Bureau of Economic Research Cambridge, Mass., USA.

Baye, F. M., \& Epo, B. N. (2011). Measuring National Income, Wealth, Poverty, and Inequality in African Countries. IARIW-SSA Conference Cape Town, South Africa.

Baye, M. F., \& Epo, N. B. (2009). Explaining Inter-Household Gender Inequality in Cameroon: An Oaxaca-Blinder Approach. Paper presented at the 65th annual congress of the International Institute of Public Finance (IIPF), in Cape Town, South Africa, from the 13th to 16th August 2009.

Becker, G. S. (1993). Human Capital: A Theoretical and Empirical Analysis, with Special Reference to Education (3rd ed.). Chicago, Illinnois: University of Chicago press. https://doi.org/10.7208/chicago/9780226041223.001.0001

Cameroon. (1998). Law No. 98/004 of $14^{\text {th }}$ April 1998 to lay down guidelines for education in Cameroon. Yaounde: Ministry of National Education.

Chaudhry, I. S. (2007). Impact of Gender Inequality in Education on Economic Growth: An Empirical Evidence from Pakistan. The Pakistan Horizon, 60(4).

Checchi, D. (2001). Education, inequality and income inequality: Distributional Analyses. Suntory and Toyata International Centres for Economics. Research Programme Papers No. 52.

De-Gregorio, J., \& Lee, J. W. (2002). Education and income inequality: New evidence from cross country data. Review of Income and Wealth, 48(3), 395-416. https://doi.org/10.1111/1475-4991.00060

Digdowiseiso, K. (2009). Education inequality, economic growth, and income inequality: Evidence from Indonesia 1996-2005. MPRA Paper. https://doi.org/10.2139/ssrn.1602642

Finance Bill for the Year 2011. (2011). Report on the Economic, Social and Financial Situation and Prospects of 
the Nation: 2010 Financial Year. Republic of Cameroon.

Growth and Employment Strategy Paper. (GESP 2009). Reference Framework for Government Action over the period 2010-2020. Republic of Cameroon

Hausmann, R., Tyson, L. D., \& Zahidi, B. S. (2012). The Global Gender Gap Report. Geneva, World Economic Forum.

Henderson, J. V., \& Poole, W. (1991). Principles of Economics. Lexington, D.C. Health and Company.

Hill, M. A., \& King, E. M. (1993). Women’s Education in Developing Countries: An overview. In E. M King, \& M. A Hill (Eds.), Women's Education in Developing Countries: Barriers, Benefits and policies. Baltimore, John Hopkins University Press.

Hill, M. A., \& King, E. M. (1995). Women's Education and Economic Well-being, Feminist Economics, 1, 21-46. https://doi.org/10.1080/714042230

International Monetary Fund. (2003). Cameroon: Poverty Reduction Strategy Paper. IMF Country Report No. $03 / 249$

Kattan, R. B. (2006). Implementation of Free Basic Education Policy. Education Working Paper Series No. 7 , Washington D. C., World Bank.

Klasen, S. (2002). Low Schooling for Girls, Slower Growth for all? Cross-country Evidence on the Effect of Gender Inequality in Education on Economic Development. World Bank Economic Review, 16, 345-373. https://doi.org/10.1093/wber/lhf004

Klasen, S., \& Lamanna, F. (2008). The Impact of Gender Inequality in Education and Employment on Economic Growth in Development Countries: Updates and Extensions.

Lucas, R. (1988). On the Mechanics of Development Planning. Journal of Monetary Economics, 22, 3-42. https://doi.org/10.1016/0304-3932(88)90168-7

Mahmood, S., Mohd, N. Z., \& Hook, L. S. (2012). The Effect of Human Capital Inequality on Income Inequality in Developing Countries. 3rd International Conference on Business and Economic Research Bandung, Indonesia.

Meltem, I. (2010). The Role of the Female Education in Economic Development: A Case for Turkey. Turkey, Yaşar University.

Morrison et al. (2007). Gender Equality, Poverty and Economic Growth. Washington, D.C.: World Bank Policy research working paper 4349. https://doi.org/10.1596/1813-9450-4349

Nanfosso, R. A. T., \& Zamo-Akono, C. M. (2010). Fertility, Health and Female Labour Force Participation in Urban Cameroon. International Business Research, 3(2). https://doi.org/10.5539/ibr.v3n2p136

Njeuma, D. (1998). Gender Issues in Some Francophone African Universities. Forum for African Women Educationalists Newsletter (FAWE), University of Buea, Cameroon.

Njimanted, G. F. (2010). Foreign Debt, Economic Growth and Poverty Reduction in Developing Economies: The Cameroonians Experience. African Journal of Social Sciences: A Multidisciplinary Journal of Social Sciences, 1(1), 58-83.

Olaniyan, D. A., \& Okemakinde, T. (2008). Human Capital Theory: Implications for Educational Development. European Journal of Scientific Research, 24(2), 157-162.

Pervaiz, Z., Ghani, M., Admad, S., \& Chaudhry, A. R. (2011). Gender Inequality and Economic Growth: A Time Series Analysis for Pakistan. Middle -East Journal of Scientific Research, 10(4), 439-439.

Pose, \& Tselios, V. (2009). Education and Income Inequality in the Regions of the European Union. Journal of Regional Science, 49(3), 411-437. https://doi.org/10.1111/j.1467-9787.2008.00602.x

Psacharopoulos, G., \& Woodhall, M. (1997). Education for Development: An Analysis of Investment Choice. New York, Oxford University Press.

Romer, P. M. (1990). Endogenous Technological Change. Journal of Political Economy, 71-102. https://doi.org/10.1086/261725

Tilak, J. B. (1989). Education and its relation to economic growth, poverty and income Distribution. Washington, D.C.: World Bank

Tinbergen, J. (1972). The impact of education on income distribution. Review of Income and Wealth, 18(3), 
255-265. https://doi.org/10.1111/j.1475-4991.1972.tb00865.x

UNDP. (1995). Human Development Report 1995. Oxford: OUP

UNICEF. (2009). Division of Policy and Practice, Statistics and Monitoring Section. Retrieved from http://www.childinfo.org

World Bank. (1994). Cameroon: Diversity, Growth and Poverty Reduction. Human Resource and Poverty Division, Africa Region. World Bank, Washington.

\section{Appendix}

\section{Table A1. Description of variables}

\begin{tabular}{|c|c|c|}
\hline Variables & Description & Source \\
\hline LGDP & Real Gross Domestic Product (GDP) per capita & $\begin{array}{l}\text { World Development indicators (WDI). } \\
\text { Website: http://www.wdi.worldbank.org }\end{array}$ \\
\hline LIN & $\begin{array}{l}\text { natural logarithm of capital investment. Capital investment in this study is } \\
\text { measured as gross fixed capital formation }\end{array}$ & $\begin{array}{l}\text { World Development indicators (WDI). } \\
\text { Website: http://www.wdi.worldbank.org }\end{array}$ \\
\hline LOPEN & $\begin{array}{l}\text { natural logarithm of trade, The sum of exports and imports of goods and } \\
\text { services measured as a share of gross domestic product. }\end{array}$ & $\begin{array}{l}\text { World Development indicators (WDI). } \\
\text { Website: http://www.wdi.worldbank.org }\end{array}$ \\
\hline LTHEIL & $\begin{array}{l}\text { Income inequality proxied by Theil coefficient ranges between } 0 \text { and } 1 \text {. } \\
\text { Where } 0 \text { means perfect equality (complete equality) and } 1 \text { implies perfect } \\
\text { inequality ( } 100 \% \text { or complete inequality). }\end{array}$ & $\begin{array}{l}\text { World Development indicators (WDI). } \\
\text { Website: http://www.wdi.worldbank.org }\end{array}$ \\
\hline LEG & $\begin{array}{l}\text { LEG is the natural logarithm of educational gender gap. Educational gender } \\
\text { gap is measured as the ratio between female and male primary, secondary } \\
\text { and tertiary enrolment. Educational gender gap coefficient ranges between } \\
0 \text { and } 1 \text {. Where } 0 \text { indicates perfect inequality in the distribution of } \\
\text { education and } 1 \text { means perfect equality in the distribution of education }\end{array}$ & $\begin{array}{l}\text { World Development Indicators (WDI). } \\
\text { Website: http://www.wdi.worldbank.org }\end{array}$ \\
\hline LAD & $\begin{array}{l}\text { natural logarithm of age dependency ratio Age dependency ratio in this } \\
\text { study is captured as the ratio of the dependents (people younger than } 15 \text { and } \\
\text { older than 64) to the working-age population (those ages 15-64) }\end{array}$ & $\begin{array}{l}\text { World Development Indicators (WDI). } \\
\text { Website: http://www.wdi.worldbank.org }\end{array}$ \\
\hline LFPR & $\begin{array}{l}\text { labour force participation rate. Labour force participation rate represents } \\
\text { the differences between women and men in labour participation }\end{array}$ & $\begin{array}{l}\text { CEPII (Centre d'Etudes Prospectives et } \\
\text { d'Informations Internationales). } \\
\text { Website: http://www.cepii.fr }\end{array}$ \\
\hline LFT & $\begin{array}{l}\text { female teachers in the Labour force ( } \% \text { of teachers who are female). Female } \\
\text { labour force as a percentage of the teachers shows the extent to which } \\
\text { women are active in the labour force }\end{array}$ & $\begin{array}{l}\text { CEPII (Centre d'Etudes Prospectives et } \\
\text { d'Informations Internationales). } \\
\text { Website: http://www.cepii.fr }\end{array}$ \\
\hline
\end{tabular}

\section{Copyrights}

Copyright for this article is retained by the author(s), with first publication rights granted to the journal.

This is an open-access article distributed under the terms and conditions of the Creative Commons Attribution license (http://creativecommons.org/licenses/by/4.0/). 